\title{
O FURACÃO E AS ASSIMETRIAS DOS FLUXOS CULTURAIS
}

Uma primeira imagem me veio, ao recordar da convivência com o colega e amigo José Luís Jobim de Salles Fonseca, a do furacão, cuja passagem assistimos, logo ao término de um evento sobre Machado de Assis, na Casa de las Américas, em Havana. Seus giros avassaladores perturbaram a vida dos povos do Caribe. Jobim chegou mesmo a tomar o avião para voltar ao Brasil, mas os efeitos dos ventos do furacáo que se aproximava fizeram literalmente que o aviáo batesse asas ao se aproximar da cabeceira da pista de decolagem. Resultado, o aviáo não decolou, e o amigo teve de se abrigar em um hotel. Não foi para aquele de onde havia saído para o embarque, porque havia a possibilidade de inundação das ruas de seu entorno. Estava próximo do oceano, como também a Casa de las Américas. Dirigiu-se, então, ao meu hotel, que ficava numa região mais alta da cidade. E, lá, nos encontramos, sem que pudéssemos ficar em nossos quartos, situados nos andares superiores: as janelas eram de vidro e, embora reforçadas por largas fitas de papel grosso, poderiam não resistir e os quartos seriam inundados. Ficamos, de forma solidária, no lobby do hotel, onde havia vários bares e restaurantes, tomando mojitos, refletindo sobre a situação literária e cultural entre os países iberoamericanos e observando os coqueiros, em torno do hotel, que se inclinavam, mas não se partiam. Estavam solidamente presos ao chão.

E o furacão varreu a ilha e não foi registrado nenhum acidente grave. Havia uma solidariedade geral no país, preparado para receber anualmente furacôes similares, numa prática quase rotineira. Valho-me dessas imagens para associá-las, desde as conversas descontraídas, como as do lobby do hotel, até as discussóes em congressos e também os artigos e livros publicados pelo colega e amigo. Em nossa área, podemos associar os furacôes às fortes assimetrias dos fluxos culturais, que varrem a teoria e crítica literárias em dimensão planetária. E só conseguem fazê-lo - como nos volteios dos furacôes - a custo de polarizaçóes que não admitem mediaçóes. E são essas mediaçôes, sem perder sua base no solo - como na resistência dos coqueiros - que podemos ler as muitas publicaçóes do colega. Só para exemplificar, podemos citar o título Literatura e cultura: do nacional ao transnacional (Rio de Janeiro: Eduerj, 2013).

O mundo é visto, então, em rede, em que as polaridades se interpenetram e são híbridas. Toda identidade é plural, pressupóe uma 
somatória de caracteres que emergem de acordo com as situaçôes contextuais. Por isso, não podemos nos restringir aos fluxos assimétricos que, como furacôes da moda, penetram o discurso crítico, nas mídias e na universidade. Veio o furacão da globalizaçáo a sufocar o polo oposto, o da nacionalidade. Esta, por sua vez, não pode se restringir à posição de um Jeca, de Monteiro Lobato. A essa imagem, esse nosso escritor acrescentou depois a imagem de Zé Brasil. E reflexóes em que o desenvolvimento se alinhou com articulaçôes entre o nacional e o supranacional. E são essas articulaçóes, em termos de literatura e de cultura, que encontramos nas publicaçóes de Jobim.

Essa é a dimensão espacial, que encontramos nos textos do crítico brasileiro, mas as imbricações também são de ordem temporal. Há um repertório e um conjunto de habitus que seguem nossa trajetória histórica. Inclusive, como aponta, fixações provenientes dos tempos coloniais, que são diferentes daqueles da colonização norte-americana e canadense. Muito da maneira de ser do colonizado, diríamos, ainda persiste. No caso, aceitando as assimetrias dos fluxos culturais, sem sentido crítico, o furacão globalizador. Não se apercebe que a efetiva globalização pressupóe reciprocidade e que ela não existe. Aprendemos com a experiência do outro, hegemônico ou não, uma experiência diferente da nossa. Para tanto, exige-se uma postura crítica, como demonstra Jobim em suas reflexôes, seja em relação a outras situaçôes da atualidade, seja em relação ao nosso percurso histórico. Logo, que nos assumamos como sujeitos do conhecimento e vendo os outros também na condição de sujeitos.

São repertórios literários e culturais que circulam, como desenvolve Jobim. Há que considerar as suas recepçóes, que se atualizam de forma diferente, dependendo do contexto. E conectividades que se estabelecem com base nos campos intelectuais supranacionais. Para além do furacão avassalador que coloca a competitividade como uma das mais fortes inclinaçôes da ética humana, opõe-se assim, para minimizar a força desses ventos assimétricos, a solidariedade. No caso da literatura, entre colegas de universidades de diferentes países, hegemônicos ou não. Trata-se de uma experiência vivida por Jobim, que tem circulado por muitos países, em seu cursos, eventos e palestras. Um campo intelectual pautado solidariamente pelas trocas culturais. Isto é, aprender também com a experiência do outro, sem abdicar de nossa condiçấo de sujeitos. Náo nos sujeitamos assim à direção avassaladora dos ventos, mas procuramos opor-lhes a resistência comunitária supranacional, procurando soprar na direção oposta.

Para tanto, uma atitude se coloca como paradigmática: a criticidade. Não apenas em relação ao outro, mas também a nós próprios. 
É imprescindível ao crítico uma visão abrangente dos conceitos que utiliza, suas implicaçôes em rede. Inclusive em relação às outras áreas do conhecimento. Os estudos literários beneficiam-se, de forma análoga, das teorizaçóes de outras disciplinas, mas têm suas especificidades. Da mesma forma que não podemos "aplicar" mecanicamente uma teoria formulada em outros contextos e situaçôes, também não podemos reproduzir acriticamente modelos estabelecidos dessas outras áreas. Os ensaios de Jobim apontam nessa direção: domínio do instrumental crítico utilizado, relacionando-o e problematizando-o com suas bases de modelização e tendo em conta a dimensão comunicativa do texto, sempre dirigido a um leitor virtual, que hoje se vale de vários suportes.

E será dessa forma, não aceitando a "colonização" que nos vem da recepção acrítica dos fluxos culturais assimétricos e nem a "colonização" por critérios e metodologias que nos vêm de outras áreas, que os escritos de Jobim apontam para uma crítica afinada com a "nossa" razão de ser. "Nossa", assim entendida de forma relativa, por vir de nossa experiência históricocultural híbrida e que se situa num mundo atual em que as assimetrias culturais são evidentes, com o conceito de competitividade, que veio da hegemonia do campo econômico, superando o de solidariedade. E, assim, a lógica do efeito de curto prazo superando o de longo prazo, de ordem estrutural. Por oposição, surgem os blocos supranacionais, que emergem da economia para a vida cultural: os blocos comunitários ao lado dos campos intelectuais, acima referidos.

É nessa direção que o conjunto das produções críticas de Jobim nos convida a pensar. São situaçóes múltiplas, híbridas, que se interpenetram, envolvendo história, situação sociocultural e outras áreas do conhecimento. O próprio sujeito da enunciação já é formado dessa forma, como os receptores de sua mensagem. Impóe-se, pois, criticidade e abertura do campo literário para outras áreas do conhecimento, sem deixar de se colocar como sujeito híbrido, mas sujeito, e não objeto do conhecimento - é de se enfatizar.

Do nacional, isto é, neste caso, da universidade brasileira, é que se acessa a transnacionalidade, pautada de forma solidária pelas articulaçôes dos campos intelectuais supranacionais, que também aspiram por virem a se constituir blocos culturais igualmente transnacionais. As assimetrias que vêm da concentração dos ventos do furacão poderão ser, assim, atenuadas. Há que se preparar futuros críticos para receberem criticamente os furacóes das assimetrias culturais. Articulaçóes de solidariedade que possuem suas raízes no solo, como os coqueiros de Havana, mas capazes de resistirem à força dos ventos, por terem, neste caso, não apenas raízes no chão, mas articulaçôes que 
levam a um chão simbólico maior, com enlaces supranacionais. Para tanto, são imprescindíveis - como se pode depreender - articulaçóes que apontem para o alargamento de perspectivas. Uma forma de poder simbólico que tenha suas bases na força sociocultural pautada por um comunitarismo que ultrapasse as rígidas fronteiras das delimitações históricas.

Benjamin Abdala Junior (USP/CNPq) 